\title{
STRUCTURE AND CARBON STOCK OF Canarium schweinfurthii (Engl) (BURSERACEAE) IN COFFEE-BASED AGROFORESTRY SYSTEMS OF THE BAMBOUTOS, WEST CAMEROON
}

\author{
Mélanie Rosine Tsewoue ${ }^{1 凹}$, Marie Louise Avana Tientcheu ${ }^{1}$, Julius Kajoh Boyah ${ }^{2}$ (D) \\ Department of Forestry, Faculty of Agronomy and Agricultural Sciences, University of Dschang, B.P. 222 \\ Dschang, Cameroon \\ ${ }^{2}$ Department of Plant Biology, Faculty of Science, University of Dschang, B.P. 67 Dschang, Cameroon.
}

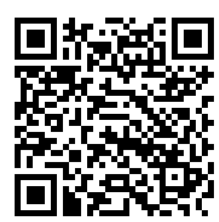

\section{ABSTRACT}

The revival of the coffee sector has led to a renewed national interest in the development of Canarium schweinfurthii, or "Aiélé", a multipurpose tree that dominates the agrarian landscape of the Western Highlands of Cameroon. This study focuses on the structure and Carbon sequestration potential of Aiélé in coffee agroforestry systems in the Bamboutos Division. The species inventory was done on 45 plots of $2400 \mathrm{~m} 2$ each within which all individuals with DBH $\geq 5 \mathrm{~cm}$ were measured. The estimate biomass and carbon stocks using the allometric models of Chave (2014). The structure in diameter classes reveals that Aiélé in coffee plantations are dominated by old stems with a near absence of futurs stems. The average biomass obtained was $144.1 \pm 27.76 \mathrm{t} / \mathrm{ha}$ for an average carbon stock

Received 16 September 2021

Accepted 16 October2021

Published 31 October2021

CorrespondingAuthor

Mélanie Rosine Tsewoue,

tsewouemel@yahoo.fr

DOI

10.29121/granthaalayah.v9.i10.2021 .4306

Funding: This research received no specific grant from any funding agency in the public, commercial, or not-for-profit sectors.

Copyright: (C) 2021 The Author(s). This is an open access article distributed under the terms of the Creative Commons Attribution License, which permits unrestricted use, distribution, and reproduction in any medium, provided the original author and source are credited. of $67.7 \pm 13.05 \mathrm{tC} / \mathrm{ha}$. This study showed that the structure of Aiélé observed in coffee plantations indicates an ageing of the orchards and an almost total absence of regeneration. For this reason, several constraints to tree planting were noted and highlighted and should be removed by technical assistance to farmers. However, the revival of coffee growing promoted by the Cameroonian government should also constitute an asset for the conservation of the species.

Keywords: Coffee Agroforests, Canarium Schweinfurthii, Carbon Stock, Structure, Cameroon

\section{INTRODUCTION}

The original vegetation of the Western Highlands of Cameroon, and of the Bamboutos Division in particular, is made of mosaics forests and savannahs more or less degraded. Demographic pressure coupled with strong land pressure has favored the development of several agricultural practices among which agroforestry systems (AFS) figure prominently Lounang et al. (2012). These more or less intensive agricultural practices depending on land availability are dominated by numerous woody species conserved in production systems for their multiple products and services Njoukam et al. (2008), Tsewoue (2013). Indeed, farmers conserve and introduce a number of trees into production systems Saj et al. (2013), Mapongmetsem et al. (2016), Honvou et al. (2021). These trees provide multiple services to the cocoa and coffee trees and also provide households with products that are involved in the self-sufficiency and food balance of families Jagoret et al. (2014), Etchiké et al. (2017). With their forest-like structure, AFS participate in the conservation of woody diversity Etchiké et al. (2017), Saj et al. (2017), Temgoua et al. (2019) and in Carbon sequestration Saj et al. (2013), Temgoua et al. (2018). 
The potential of AFS to act as Carbon sinks is increasingly being emphasized, indeed, AFS store Carbon in plant biomass, soils, and wood and non-wood products, while maintaining agricultural production Albrecht and Kandji (2003), Schoeneberger (2009), Atangana et al. (2014). Thus, they represent a promising option for sustainable environmental management. Although Carbon sequestration has long been an underutilized benefit of agroforestry Montagnini and Nair (2004), the fact remains that this environmental service is increasingly recognized and valued Kumar and Nair (2011), Temgoua et al. (2018). Similarly, AFS accumulate woody biomass according to its floristic composition and structure Tchatchouang et al. (2018), Kombate et al. (2019). Among these woody species, Canarium schweinfurthii commonly known as "Aiélé" or incense tree or black fruit trees is prominent. The interest of the tree lies mainly in its fruit production and the exploitation of its wood. Indeed, the fleshy and resinous pulp of the fruit is edible after cooking in hot water. Similarly, it is eaten along with many tubers such as cassava, yam and sweet potato Njoukam (1998). Tchouamo et al. (2000) found that in a single production season, the black fruits brought in about 27 million CFA francs in the villages of Bamboutos Division alone. In addition, the wood of C. schweinfurthii is used in light carpentry works. Indeed, it is widely used in carving and in the manufacture of utensils Tsewoue et al. (2019).

However, in the face of increasing environmental problems, there is a growing interest in assessing the ecosystem services provided by trees in research and development institutions. Indeed, the integration of trees in agroecosystems has the potential to increase soil fertility, reduce erosion, increase biodiversity, and reduce greenhouse gas content in the atmosphere through carbon sequestration Nair et al. (2009). Many other species including Chlorophora excelsa, Albizzia spp, Entandrophragma spp, Canarium schweinfurthii are generally maintained and protected in cocoa and coffee plantations for their multiple products and services Jagoret et al. (2014), Manga et al. (2013), Saj et al. (2017), Temgoua et al. (2018), Tsewoue et al. (2019). Similarly, agroforestry systems based on perennial crops such as coffee and cocoa trees by maintaining a high density of tree species in the plots for various services and uses, offer very interesting opportunities, for carbon storage Zafack et al. (2002), Saj et al. (2013), Temgoua et al. (2018). By generating many ecological services, agroforestry systems are perceived as sustainable and therefore eligible for the mechanism to reduce emissions from deforestation and forest degradation Atangana et al. (2014). Although the potential for woody diversity conservation and carbon storage in cocoa agroforestry systems in Cameroon is well documented Saj et al. (2017), Temgoua et al. (2018), the fact remains that in coffee agroforestry systems, much remains to be done.

Within the framework of the revival of coffee production by the State of Cameroon, due to the abandonment by producers because of the volatility of world coffee costs and the economic recession of the agricultural sector in the 1980s Annonymous (2012), we are increasingly observing a renovation and extension of orchards. The availability of appropriate technologies therefore requires the acquisition of information on the structure and sequestration potential of trees in coffee agroforestry systems. Hence, the objective of the study was to determine the structure of the stand of C. schweinfurthii and to estimate its biomass and its potential for carbon sequestration in the coffee agroforestry systems in the Bamboutos Division. 


\section{MATERIALS AND METHODS \\ 2.1. STUDY AREA}

Data were collected in three major clusters (Babeté, Bafounda and Bamougong) in the Bamboutos Division (Figure 1). With an area of $1155 \mathrm{~km} 2$, Bamboutos Division is located between $5^{\circ}$ and $6^{\circ}$ North latitude and between $9^{\circ}$ and $11^{\circ}$ East longitude. It is home to a population of 140,000 (PCD, 2013). It is a highland area, with an altitude of above $1100 \mathrm{~m}$ above sea level. The climate is characterized by a rainy season that lasts nearly 8 months with a relatively moderate total rainfall (about $1600 \mathrm{~mm}$ of rainfall per year). The major activity practiced in this part of the country is trade and agriculture which occupy more than $80 \%$ of the active workforce. A combination of a polyculture system in two annual cycles is generally practiced, where perennial crops (coffee, fruit trees) are often in association with annual crops in a complex combination Manga et al. (2013).

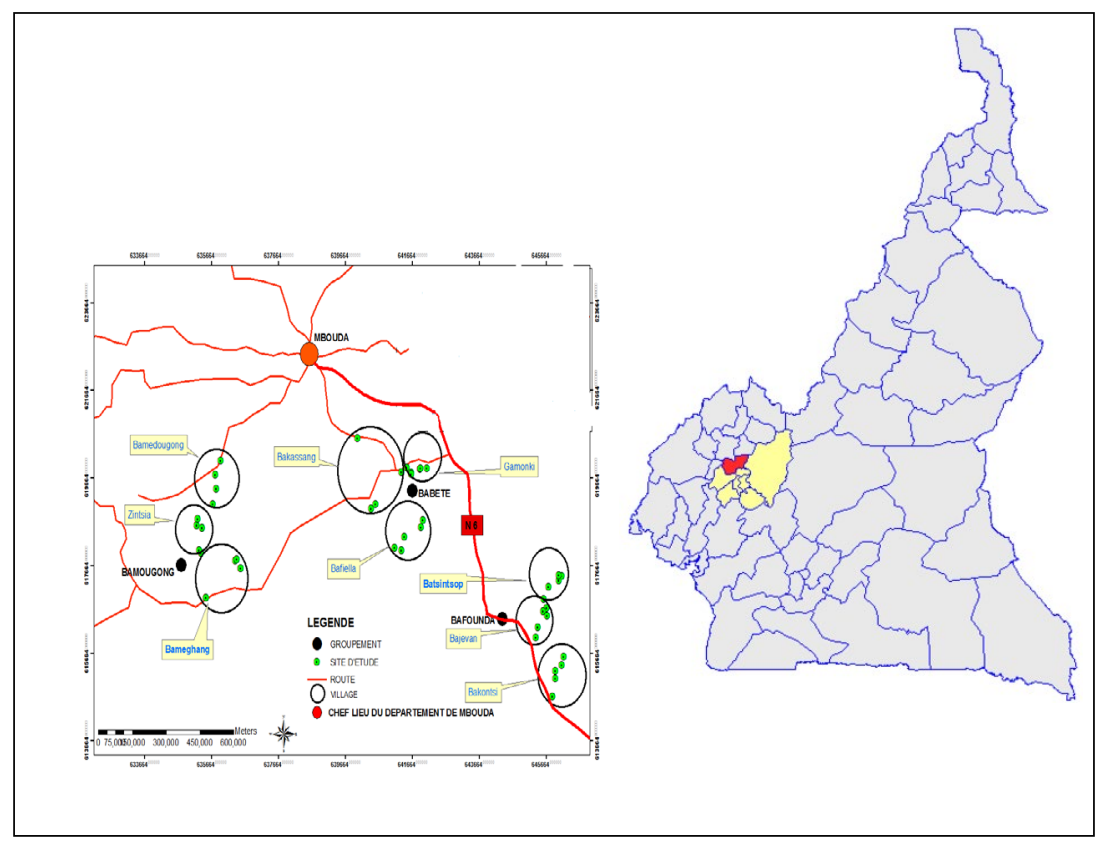

Figure 1 Localisation map of the study area: Source: ICRAF (2012)

\subsection{STUDIED SPECIES}

Canarium schweinfurthii (Engl) is a species of the Burseraceae family. It is an ombrophilous species native to the forests of the Ethiopian highlands; it is widespread in sub-Saharan Africa and can reach 25 to $40 \mathrm{~m}$ in height with a trunk of about $1.50 \mathrm{~m}$ in diameter Njoukam and Peltier (2002). Its base is slightly conical or with a serif. Its straight, cylindrical bole has a very branchy crown with clumped foliage consisting of large leaves grouped in stars at the ends of the branches (Photo 1 ). The leaves are in a stelescent bundle of about ten at the end of the branches, deciduous, and alternate. They can reach $60 \mathrm{~cm}$ in length with a sub aligned petiole going to 12 pairs of opposite leaflets. The leaf blade is lanceolate or elliptical, measuring $8.5 \times 6 \mathrm{~cm}$. The tree bears fruit from the age of 8 years and grows in height and diameter (4 cm every year) Njoukam (1998). The inflorescence has whitish, campanulate flowers that can reach $1 \mathrm{~cm}$ in height, trimerous, 6 stamens in the male flowers, 3-locular ovary in the female flowers. The fruits (Photo 2) are ellipsoidal 
drupes purplish at maturity, from 3 to $4 \mathrm{~cm}$ in length and 1.2 to $2 \mathrm{~cm}$ in diameter of appearance close to the fruits of olive tree), from where the name "African olives" is obtained. A fruit can have an average mass of $7 \mathrm{~g}$, i.e., $50 \%$ for the pulp and $50 \%$ for the seed CTFT (1989).

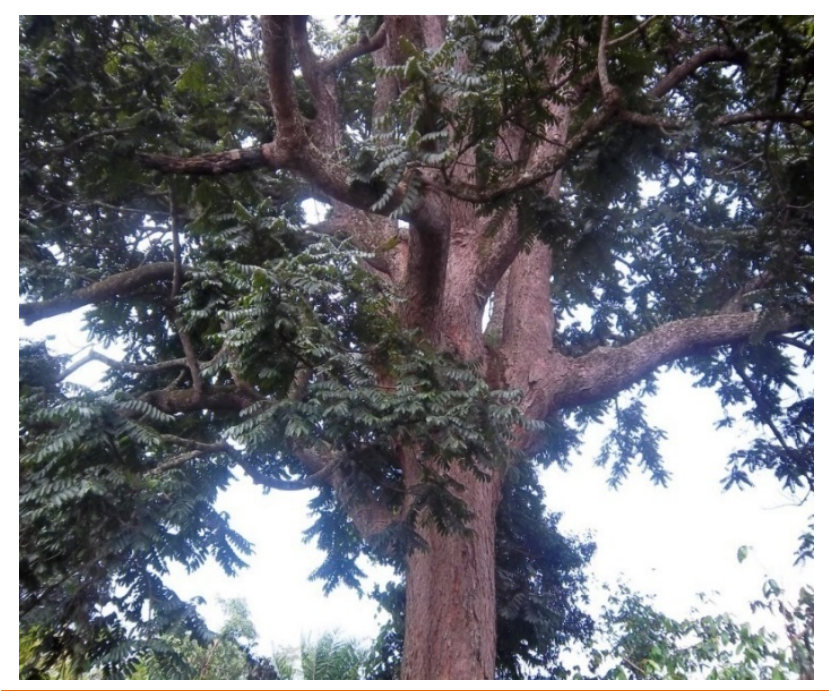

Photo 1 Patial view of the crown of C. schweinfurthii

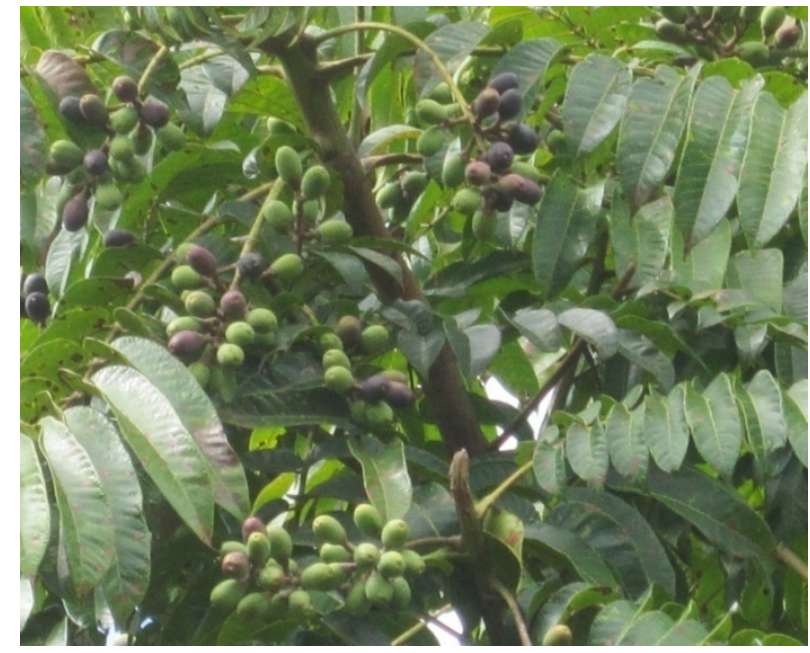

Photo 2 Branch of C. schweinfurthii with leaves, mature fruits (violet colour) and immature fruits (green colour)

\subsection{DATA COLLECTION}

The inventory was carried out in 45 coffee plantations, that is, 15 plantations per cluster of localities, chosen randomly with the only selection criterion being the presence of C. schweinfurthii in the plot. In each plantation, a counting device was set up by adapting the method described by Hairiah et al. (2010) with the installation of rectangular main plots of $2400 \mathrm{~m} 2(40 \mathrm{~m} \mathrm{X} 60 \mathrm{~m})$ for the counting of individuals with a diameter at chest height greater than or equal to $30 \mathrm{~cm}$ and secondary plots of $800 \mathrm{~m} 2(20 \mathrm{~m} \mathrm{X} 40 \mathrm{~m})$ for individuals with a diameter between $5 \mathrm{~cm}$ and $30 \mathrm{~cm}$. Measurements of diameter, total height and bole were taken, with stands less than $10 \mathrm{~cm}$ in diameter classified as potential regenerations Dourma et al. (2011). Species heights were measured with a clinometer and diameters with a 
tape measure. The areas, ages of the plantations, and the origin of the trees (retained or introduced) were provided by the owners. The average size of the plantations was 2.5 ha.

\subsection{DATA PROCESSING}

The collected data were entered into the Microsoft Excel ${ }^{\circledR} 2013$ spreadsheet. The distribution of stands by height and diameter classes was adjusted Glèlè Kakaî et al. (2016). Statistical analyses were performed using SPSS (Statistical Package for Social Science version 21.0) software. Structural variables were calculated according to the formulas:

Density (D): D = (Ni/Si) 0.0001

Average diameter (Dm): Dm $\sum d i / N i$

Basal area (G): $\mathrm{G}=\pi \mathrm{di}^{2} / 4$

where $\mathrm{Ni}=$ number of individuals present from group $\mathrm{i}, \mathrm{Si}=$ area of group $\mathrm{i}$, and $\mathrm{di}=$ diameter of individual $\mathrm{i}$.

Distribution histograms were constructed by $50 \mathrm{~cm}$ diameter class and $10 \mathrm{~m}$ height class to account for the demographic structure of C. schweinfurthii stands.

\section{Biomass Estimation}

The aboveground biomass of C. schweinfurthii trees was estimated using the allometric equation of Chave et al. (2014)

$\mathrm{BA}=0,0673 \times\left(\rho \mathrm{D}^{2} \mathrm{H}\right){ }^{0,976}$.

Where: $\mathrm{BA}=$ tree aboveground biomass (in $\mathrm{kg}$ ); $\mathrm{D}=$ tree diameter (in $\mathrm{cm}$ ); $\mathrm{H}=$ total tree height (in $\mathrm{m}$ ) and $\rho=$ tree specific gravity $(0,48$ g.cm-3) Vivien and Faure (2012).

The estimation of belowground biomass of each standing individual conformed to the guidelines established by IPCC (2006). According to these, the root biomass equivalence of standing woody plants is found by multiplying the value of aboveground biomass (BA) by a coefficient $R$ whose value is estimated to be 0.24 .

$\mathrm{BS}=\mathrm{BA} \times \mathrm{R}$

Where: $\mathrm{BS}=$ below-ground biomass; $\mathrm{BA}=$ above-ground biomass and $\mathrm{R}=$ root/stem ratio.

The evaluation of carbon stocks was obtained by multiplying the sum of biomass (above and below ground) by the ratio CF (carbon fraction) which is 0.47 (IPCC, 2006).

$$
\mathrm{SC}=(\mathrm{BA}+\mathrm{BS}) \times 0.47
$$

Where: $\mathrm{SC}=$ total carbon stock, $\mathrm{BA}=$ aboveground biomass and $\mathrm{BS}=$ belowground biomass.

\section{RESULTS}

\subsection{CHARACTERISTICS OF C. SCHWEINFURTHII PRODUCTION SYSTEMS IN THE BAMBOUTOS}

In Bamboutos Division, C. schweinfurthii is present in 4 types of production systems, namely coffee plantations, food crops, fallow lands and home gardens (Table 1). 


\begin{tabular}{|c|c|c|c|c|}
\hline Characteristics & $\begin{array}{l}\text { Woody } \\
\text { diversity }\end{array}$ & $\begin{array}{l}\text { Main staple } \\
\text { crops }\end{array}$ & $\begin{array}{c}\text { Average } C . \\
\text { schweinfurthii } \\
\text { density }\end{array}$ & $\begin{array}{l}\text { C. schweinfurthii } \\
\text { layout }\end{array}$ \\
\hline \multicolumn{5}{|l|}{$\begin{array}{l}\text { Production } \\
\text { systems: }\end{array}$} \\
\hline Coffee fields & 14 species & Coffee & 1 to 4 stands & $\begin{array}{l}\text { Upper tree stratum, } \\
\text { center of plantation }\end{array}$ \\
\hline Food fields & 5 species & $\begin{array}{l}\text { Zea mays, } \\
\text { P. vulgaris }\end{array}$ & 1 to 2 stands & $\begin{array}{l}\text { On the edge or inside } \\
\text { the plantations. }\end{array}$ \\
\hline Fallows & 15 species & $\begin{array}{l}\text { Abandoned } \\
\text { coffee }\end{array}$ & 1 to 3 stands & Inside plantations \\
\hline Home gardens & 6 species & $\begin{array}{l}\text { Zea mays, } \\
\text { Musa sp., } \\
\text { Coffee, }\end{array}$ & 1 to 2 stands & $\begin{array}{l}\text { Behind the huts, in the } \\
\text { yard, } 20 \mathrm{~m} \text { to } 50 \mathrm{~m} \text { from } \\
\text { the huts }\end{array}$ \\
\hline
\end{tabular}

Coffee-based production systems: They are observed around the houses or miles away from them. Coffee farmers make these systems more complex by integrating trees with various functions. Among the trees cited by farmers as part of their systems are species such as: Persea americana, Dacryodes edulis, Cola sp., Psidium guajava, Mangifera indica, Ficus sp, Spathodea campanulata, Pseudopondias microcarpa, Polysia fulva, Cecropia cecropoîdes, Entandrophragma cylindricum, and Canarium schweinfurthii etc. in these systems, C. schweinfurthii is one of the largest species that dominate the upper tree stratum.

Food production systems: in these systems all coffee trees have been felled for the production of food crops. The staple crops are annual or biennial plants such as Zea mays, Phaseolus vulgaris, Xanthosoma sagittifolium, Manihot esculenta, Arachis hypogea, Ipomoea batatas, Colocasia esculenta, Abelmoschus esculenta, Cucurbita melo, Dioscorea sp. There are also a few woody species such as Persea americana, Dacryodes edulis, Cola $s p$, is maintained at the edge or inside the plantations, dispersed at very low density.

Fallows: These are generally former coffee fields or food-producing agro systems that have been abandoned for at least two years. Many woody species such as Ficus sp., Spathodea campanulata, Pseudopondias microcarpa, Polysia fulva, Ceiba pentandra, Cecropia cecropoides, Entandrophragma cylindricum, and fruit trees such as Persea americana, Dacryodes edulis, Cola sp. In these systems, C. schweinfurthii is dispersed indoors and at low density ( 1 to 3 plants per plot).

Hut gardens: These are generally observed around dwellings. They integrate annual, biennial, perennial and semi-perennial crops such as Zea mays, Phaseolus vulgaris, Xanthosoma sagittifolium, Manihot esculenta, Arachis hypogea, Allium sepa, Coffea arabica, Musa sp., Solanum tuberosum, Dioscorea spp, Ipomoea batatas, Colocasia esculenta, Abelmoschus esculenta, Cucurbita melo) as well as domesticated animals. There are fruit trees (Persea americana, Dacryodes edulis, Cola sp., Mangifera indica), and forage legumes. C. schweinfurthii is maintained behind the huts, in the middle of the yard and sometimes 20-50 m from the dwellings. 


\subsection{STRUCTURAL PARAMETERS OF TREES IN THE STUDY LOCALITIES}

\subsubsection{DENSITY AND AVERAGE BASAL AREA OF SCHWEINFURTHII TREES IN THE CLUSTERS}

Overall, 62 individuals were recorded in a total area of 8.29 ha. Table 2 shows the average density of trees recorded per cluster. The average density of C. schweinfurthii trees varied between clusters. On average, there are $2.56 \pm 1.86,1.19$ \pm 0.57 and $9.97 \pm 5.16$ trees/ha in the Babeté, Bafounda and Bamougong clusters or localities respectively. The average basal area of trees was $4.24 \pm 1.20 ; 5.63 \pm 2.79$, and $4.67 \pm 3.40 \mathrm{~m} 2 / \mathrm{ha}$ in the Babeté, Bafounda and Bamougong localities, respectively. The Kruscal-wallis test $(\mathrm{p}<0.001)$ shows that there is a significant difference between the tree densities observed according to the localitie. On the other hand, the areas occupied by individuals were not significantly affected by the localitie $(\mathrm{p}=0.872)$.

\begin{tabular}{|cccc|}
\hline \multicolumn{2}{|c|}{ Table 2 Average Density of trees in the localities. } \\
\hline Cluster/locality & $\begin{array}{c}\text { Number of } \\
\text { trees }\end{array}$ & $\begin{array}{c}\text { Average density in } \\
\text { hectare }\end{array}$ & $\begin{array}{c}\text { Average basal area } \\
\text { m }\end{array}$ \\
\hline Babeté & 24 & $2,56 \pm 1,86 \mathrm{a}$ & $4,24 \pm 1,20$ \\
\hline Bafounda & 17 & $1,19 \pm 0,57 \mathrm{a}$ & $5,63 \pm 2,79$ \\
\hline Bamougong & 21 & $9,97 \pm 5,16 \mathrm{~b}$ & $4,67 \pm 3,40$ \\
\hline Total & 62 & $13,72 \pm 11,02$ & $14,54 \pm 9,74$ \\
\hline
\end{tabular}

Values on the same column with the same letter are not significantly different at $5 \%$

\subsubsection{STRUCTURE OF THE TREES SURVEYED BY VILLAGES}

The structure of C. schweinfurthii trees varies, depending either on the age of the individuals or on the management mode by the owner. The results obtained show that the height structure of C. schweinfurthii trees in the coffee plantations presents the appearance of a bell, with a mode in class 21 - 30 in the three villages (Figure 2) and also constitutes the maximum average height in the three groups, thus translating that the trees in the plantations are made up of large trees. Small trees (height $<10 \mathrm{~m}$ ) are almost absent in all the villages studied. This indicates a lack of regeneration of both natural and artificial species in the study area.

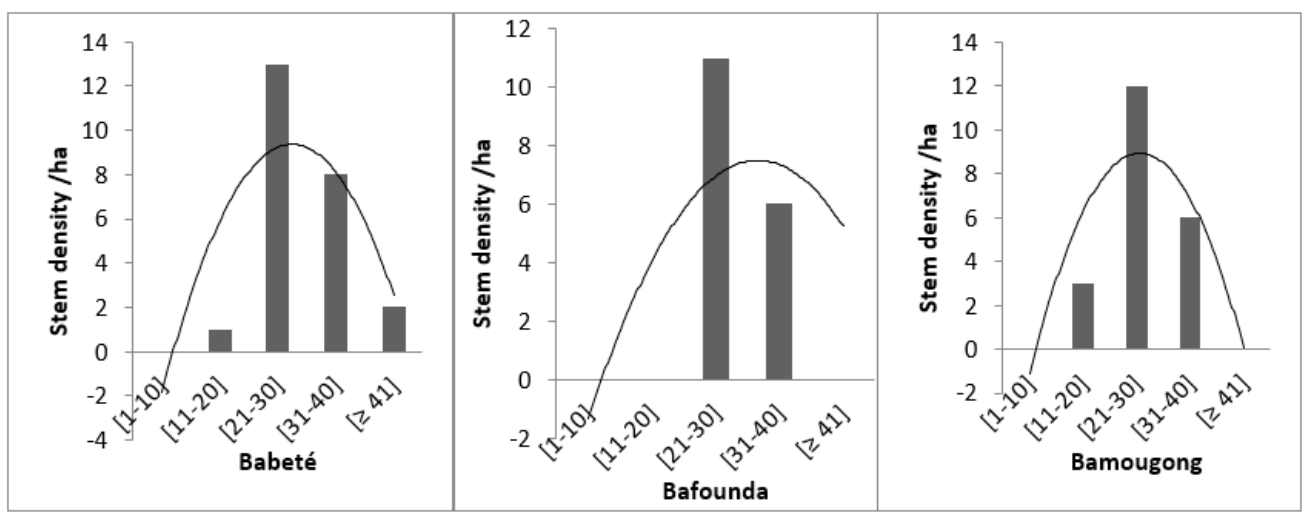

Figure 2 Stem structure of C. schweinfurthii in Babeté, Bafounda and Bamougong clusters respectively 
Similarly, the diametric structure of C. schweinfurthii trees varies between clusters (Figure 3). The diameter classes between 51-100 cm (41.93\%) and 101-150 $\mathrm{cm}(33.87 \%)$ are the most represented. In Bafounda, there is an almost complete absence of individuals of diameter class $\leq 50 \mathrm{~cm}$. In the other two clusters, young individuals of class $\leq 50 \mathrm{~cm}$ are weakly represented. On the other hand, we recorded a high representativeness of individuals between the classes [51 and $150 \mathrm{~cm}$ ] and a low number of individuals of large diameter $[\geq 200 \mathrm{~cm}]$. The low proportion of small diameter individuals means that the regeneration rate is low and is an indicator of an impossible reconstitution of the orchards. The presence of a few stems of largediameter individuals indicates that the production systems in the clusters are disrupted by actions such as logging.

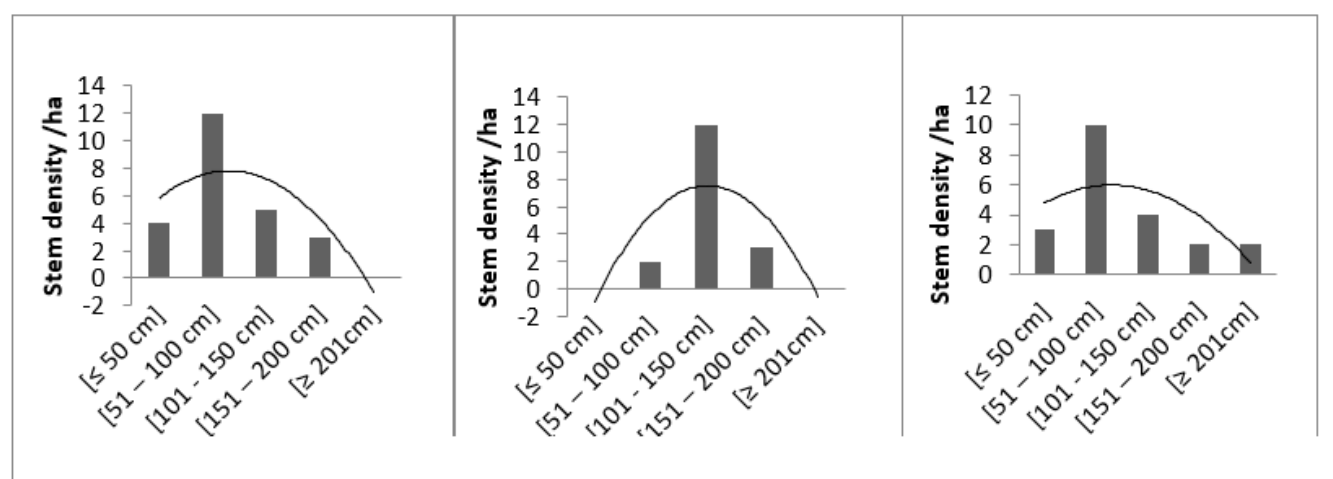

Figure 3 Structure diamétrique de C. schweinfurthii respectivement dans les groupements

The average total biomass is estimated at $144.1 \pm 27.76 \mathrm{t} /$ ha over the entire 8.29 ha surveyed. Its distribution is $81.29 \pm 11.96 \mathrm{t} /$ ha for the Babeté clusters, $113.39 \pm 31.42 \mathrm{t} / \mathrm{ha}$ for the Bafounda clusters and 237.35 $\pm 71.82 \mathrm{t} / \mathrm{ha}$ for the Bamougong clusters (Table 3). Aboveground biomass was estimated at $121.28 \pm 23.93 \mathrm{t} / \mathrm{ha}$ and belowground biomass at $22.74 \pm 3.83 \mathrm{t} / \mathrm{ha}$.

The amount of carbon stored by C. schweinfurthii trees was assessed and shows that carbon stocks of C. schweinfurthii trees differed among clusters. C. schweinfurthii trees surveyed stored an average of $38.22 \pm 5.63 \mathrm{tC} / \mathrm{ha}, 53.36 \pm 14.22$ t/Cha and $111.60 \pm 33.76 \mathrm{tC} / \mathrm{ha}$, respectively for the Babeté, Bafounda and Bamougong clusters. C. schweinfurthii trees in the Bamougong cluster store more carbon. The Kruscal-wallis test $(\mathrm{p}=0.001)$ shows that the amount of carbon sequestered by trees from the Bamougong cluster differs significantly from those from the other villages. This difference is related to the diameter and basal area of the trees, which increases with age. In contrast, the amount of carbon sequestered by trees from the Bafounda and Babeté clusters did not differ significantly $(\mathrm{p}=0.861)$.

\begin{tabular}{ccccccc}
\hline \multicolumn{5}{c}{ Table 3 Biomasse et stock de carbone des arbres de C. schweinfurthii dans les groupements } \\
\hline $\begin{array}{c}\text { Cluster/Locali } \\
\text { ty }\end{array}$ & $\begin{array}{c}\text { Abovegroun } \\
\text { d Biomass } \\
\text { (AB, t/ha) }\end{array}$ & $\begin{array}{c}\text { Undergrou } \\
\text { nd Biomass } \\
\text { (BA, t/ha) }\end{array}$ & $\begin{array}{c}\text { Total } \\
\text { Biomass } \\
\text { (TB, t/ha) }\end{array}$ & $\begin{array}{c}\text { Stock } \\
\text { carbon } \\
\text { (TB, tC/ha) }\end{array}$ & $\begin{array}{c}\text { Equivalent } \\
\text { carbon (EqC, } \\
\text { t/ha) }\end{array}$ \\
Babeté & $67,26 \pm 10,06$ & $14,03 \pm 1,91 \mathrm{a}$ & $81,29 \pm 11,96$ & $38,20 \pm 5,63 \mathrm{a}$ & $140,08 \pm 20,64$ \\
& $\mathrm{a}$ & & $\mathrm{a}$ & & $\mathrm{a}$
\end{tabular}




$\begin{array}{cccccc}\text { Bafounda } & 94,85 \pm 26,97 & 18,54 \pm 4,57 \mathrm{a} & 113,39 \pm 31,4 & 53,29 \pm 14,82 & 195,39 \pm 54,35 \\ & \mathrm{a} & & 2 \mathrm{a} & \mathrm{a} & \mathrm{a} \\ \text { Bamougong } & 201,72 \pm 62,0 & 35,63 \pm 9,76 \mathrm{~b} & 237,35 \pm 71,8 & 111,55 \pm 33,7 & 409,01 \pm 123,7 \\ & 6 \mathrm{~b} & 2 \mathrm{~b} & 6 \mathrm{~b} & 6 \mathrm{~b}\end{array}$

Values on the same column with the same letter are not significantly different at $5 \%$

\section{DISCUSSION}

In Bamboutos Division, Canarium schweinfurthii is a widespread species in the agrarian space of the Division. It is protected and/or conserved in plantations by the populations. A total of 62 trees of C. schweinfurthii were observed in the coffee plantations of the Babeté, Bafounda and Bamougong clusters on a total area of 8.29 ha. The average total density was $7.47 \pm 2.68$ plants/ha with the highest density observed in Bamougong ( $9.97 \pm 5.16$ plants/ha). This high density is justified by the fact that this village is located in rural area of the Western Highlands of Cameroon and the others in the urban (Babeté) and peri-urban (Bafounda) areas. This corroborates the observations made by Manga et al. (2013) who found that in the Western Highlands of Cameroon, C. schweinfurthii was very present in coffee farms. Similarly, this result could be explained by the interest that farmers have in this species in the locality despite the abandonment of coffee plantations due to the drop in sale prices.

Analysis of the stem structure of C. schweinfurthii in coffee plantations showed a bell-shaped pattern, with the mode in class 21- 30 in the 3 clusters. Smaller trees (height $<20 \mathrm{~m}$ ) were almost absent in all studied clusters. Similarly, the diametric structure of trees in each cluster showed a low representativeness of small diameter individuals $(\leq 50 \mathrm{~cm})$ and large trees $(\geq 200 \mathrm{~cm})$. This structuring of trees observed by diameter and height class shows a near absence of young individuals in the fields and therefore could indicate a difficulty of both natural and artificial regeneration of this species in the study area. This result could be explained by the difficulties faced by farmers in obtaining seedlings due to its low germination capacity. In addition, the late fruiting and non-productivity of some trees considerably discourages farmers from introducing them into the fields and, consequently, they limit themselves to protecting the wild species present on the farms and refrain from taking planting initiatives. These results justify those obtained by Njoukam (1997) who showed that the intensification of its production was hampered by the low germinative potential of its seeds, in addition to a low aptitude for cuttings and layering. Similarly, Njoukam and Peltier (2002) showed that the dioeciousness of Aiélé was a handicap for its propagation in rural areas because when transplanting a seedling from the seed, the farmer cannot know whether it is a male or female plant. In addition, the large size of the trees is a constraint for the exploitation of its fruits by the farmers. Indeed, this difficulty has favored the emergence of a new category of actors represented by professional climbers in the sector Tsewoue et al. (2019). The latter generally serve as intermediaries between producers and traders and take charge of harvesting and purchasing all fruit production. This strategy contributes to significantly reduce the income generated by the sale of the fruits to the climber and in turn the interest of the species for the local farmers.

Biomass and carbon stocks are essential for the implementation of climate change mitigation strategies, particularly the mechanism for reducing emissions from deforestation and degradation (REDD+). Over the entire study area, carbon stock estimates are $203.04 \mathrm{tC} / \mathrm{ha}$ with a total biomass amount of $432.03 \mathrm{t} / \mathrm{ha}$. These 
results show that Aiélé has a high potential for carbon sequestration in coffee farms. The carbon stock is higher in the Bamougong group than in the other two clusters. The high biomass values obtained could be explained by the high representation of large trees in the locality. These values are much higher than those obtained by Albrecht and Kandji (2003) on other agroforestry species such as Tephrosia candida, Grevillia robusta, Eucalyptus saligna and S. sesban. However, these results are lower than those obtained by Atiojio (2012) on Dacryodes edulis, which showed that the species could sequester up to 317 tons of $\mathrm{C} 02$ /ha at only 11 years of age. Indeed, carbon storage is proportional to the amount of tree biomass and several factors can influence its storage. Carbon fluxes exhibit significant spatial variability, mainly related to variability in soil-climate conditions, management patterns, vegetation types, and use patterns Ago (2016), Kombate et al. (2019). A variety of factors influence the variability of tree biomass. In tropical rainforests, a tree's biomass is primarily influenced by trunk diameter, crown diameter, and wood density Henry (2010). The capacity of a system to store carbon depends mainly on the forest species that compose it and the diameter classes of the trees; environmental factors and tree-specific factors Tsoumou et al. (2016), Temgoua et al. (2018). Environmental factors that may influence carbon uptake by Aiélé in Bamboutos coffee plantations would include topography, plant distribution, soils, system management, pest tolerance, age, structure and land use type. Some of these factors are tree-specific that may affect carbon storage and even the growth strategy of the species Kombate et al. (2019).

\section{CONCLUSION AND RECOMMENDATIONS}

The agrarian landscape in Bamboutos Division is marked by the presence of several introduced and/or conserved trees, including the Aiélé (Black fruits tree), which, because of its highly developed crown, is easily recognized and well known by the population. The diametric structure of the species remains dominated by large diameter and tall stands. The species in coffee plantations is aging with a near absence of young individuals. These trees contribute to climate regulation through their capacity to store carbon, which is a service recognized and valued for the reduction of greenhouse gas emissions (GHG) and therefore mitigation of global warming. However, the degradation of coffee plantations and the resulting mutations could negatively affect the representation of the species in the agrarian space of the Division. The protection and survival of this species in this locality requires the sensitization and training of farmers on the management methods of the species. However, the revival of coffee farming promoted by the Cameroonian government also constitutes an asset for the conservation of the species.

\section{ACKNOWLEDGEMENTS}

We would like to thank the African Network for Education in Agriculture, Agroforestry and Natural Resources (ANAFE) for funding, the World Agroforestry Centre (ICRAF) Yaoundé for supervision and the people of Bamboutos for their hospitality.

\section{REFERENCES}

Albrecht, A. \& Kandji, T.S. (2003). Carbon sequestration in tropical agroforestry systems agriculture. Ecosystems and Environment., 99(1): 15-27. Retrieved from https://doi.org/10.1016/S0167-8809(03)00138-5 
Ago, E.E. (2016). Dynamique des flux de carbone entre l'atmosphère et des écosystèmes ouest-africains : cas des forêts et savanes sous climat soudanien au Bénin. Université de Liège, Gembloux, Belgique, 45p. Retrieved from http://hdl.handle.net/2268/192739

Annonymous. (2012). Statistique de Production Nationale de Café au Cameroun. ONCC : Douala, Cameroun, 202p.

Atangana, A.; Khasa, D., Chang, S. \& Degrande, A. (2014). Agroforesterie tropicale. Département de Sciences du bois et de la forêt, Université Laval, Canada, 412p.

Atiojio, E. (2012). Influence du type de propagules de Dacryodes edulis sur les caractéristiques morphologiques des arbres et leur capacité de séquestration du carbone : Implications pour les opportunités de payement des services environnementaux. Mémoire de fin d'étude présenté en vue de l'obtention du diplôme d'Ingénieur de Conception des Eaux, Forêts et Chasses. FASA, Université de Dschang, 99p. Retrieved from https://agris.fao.org/agrissearch/search.do?recordID=QN2019001259440

Chave, J., Réjou-Méchain, M., Búrquez, A., Chidumayo, E., Colgan, M.S., Delitti, W.B.C., Duque, A., Eid, T., Fearnside, P.M., Goodman, R.C., Henry, M., Martínez-Yrízar, A. \& Mugasha, W. (2014). Improved allometric models to estimate the aboveground biomass of tropical trees. Global Change Biology., 20 : 3177 3190. Retrieved from https://doi.org/10.1111/gcb.12629

CTFT. (1989). Techniques sylvicoles de conduite des peuplements forestiers en Afrique. Ministère de la Coopération 3e édition. 565p.

Dourma, M., Batawila, K., Wala, K., Kokou, K., Bellefontaine, R., Foucault, B.D. \& Akpagana, K. (2011). Régénération naturelle des peuplements à Isoberlinia spp. en zone soudanienne au Togo. Acta Botanica Gallica., 156 (3):415 - 425. Retrieved from https://doi.org/10.1080/12538078.2009.10516167

Etchiké, D.A.B., Mapongmetsem, P.M. \& Ngassoum, M.B. (2017). Phytodiversité et stock de carbone dans les agroforêts de l'écotone du Mbam et Inoubou au Cameroun. Journal of Experimental Biology., 11(1) :9-22. Retrieved from https://doi.org/10.4314/cajeb.v11i1.2

Groupe d'Experts Intergouvernemental sur l'Evolution du Climat (GIEC). (2006). Guide pour l'inventaire national des gaz à effet de serre; agriculture, foresterie et autre usage des terres. Institute for Global Environnemental Strategies $4: 46-52$.

Glèlè Kakaî, R., Bonou, W. \& Lykke, M.A. (2016). Approche méthodologique de construction et d'interprétation des structures en diamètre des arbres. Annales des sciences Agronomiques 20 spécial Projet Undesert-UE, p 99112.

Hairiah, K., Dewi, S., Agus, F., Velarde, S., Ekadinata, A., Rahayu, S. \& van Noordwijk, M. (2010). Measuring carbon stocks across land use systems: A Manual. Bogor, Indonesia. World Agroforestry Centre (ICRAF), SEA Regional Office. $154 \mathrm{p}$.

Honvou, S.H.S., Aboh, B.A., Sewade, C., Teka, O., Gandounou, B.C., OUMOROU, M. \& Sinsin, B. (2021). Diversité floristique, structure et distribution des groupements végétaux des parcours d'accueil des transhumants dans la basse et moyenne vallée de l'Ouémé au Benin, Int. J. Biol. Chem. Sci., 15(1) : 81-96. Retrieved from https://doi.org/10.4314/ijbcs.v15i1.8 
Henry, M. (2010). Carbon stocks and dynamics in Sub Saharan Africa. Doctor of Philosophy, Paris Institute of Technology for Life, Food and Environmental Sciences (AgroParisTech) \& The University of Tuscia. 16p.

Jagoret, P., Kwesseu, J., Messie, C., Michel-Dounias, I. \& Malézieux, E. (2014). Valeurs d'usage des ligneux utilisés en agroforesterie : les cacaoyères du CentreCameroun. Bois et Forêts des Tropiques., 321: 45-54. Retrieved from https://doi.org/10.19182/bft2014.321.a31217

Kumar, B.M. \& Nair, P.K.R. (2011). Carbon sequestration potential of agroforestry systems: opportunities and challenges. Advances in Agroforestry 8 Springer., 307p. Retrieved from https://doi.org/10.1007/978-94-0071630-8

Kombate, B., Dourma, M., Folega, F., Woegan, A.Y., Wala, K. \& Akpagana, K. (2019). Structure et potentiel de séquestration de carbone des formations boisées du plateau Akposso en zone sub-humide au Togo. Afrique Science., 15(2) : 70-79. Retrieved from http://www.afriquescience.net/AS/15/7.pdf

Lounang, T.F.C., Tchagang, N.E.R., Youta, H.J. \& Grozavu, A. (2012). Problématique de la conservation des formations végétales residuelles à Batoufam dans les Hautes Terres de l'Ouest Cameroun, Scientific Annals of "Alexandru Ioan Cuza" University of Iaşi, Romania., 58(2): 89-104. Retrieved from https://core.ac.uk/download/pdf/268087209.pdf

Manga, M.A., Akoa, A., Abolo, D., Mbang, A.A., Mouen, B.J, Nomo, B.L. \& Akume, N.D. (2013). Structure et composition floristique des agroforêts à base de caféiers Arabica (Coffea arabica L.) dans les hauts plateaux de l'Ouest du Cameroun, International Journal of Biology and Chemistry., 7(4) :14741489. Retrieved from https://doi.org/10.4314/ijbcs.v7i4.5

Mapongmetsem, P.M., Etchiké, D. \& Ngassoum, M.B. (2016). Conservation et valorisation de la biodiversité dans les forêts de la zone périurbaine de la ville Bafia (Région du centre au Cameroun). Revue scientifique et technique Forêt et Environnement du Bassin du Congo., 6 : 60-69. Retrieved from https://core.ac.uk/download/pdf/144773496.pdf

Montagnini, F. \& Nair, P.K.R. (2004). Carbon sequestration: an underexploited environmental benefit of agroforestry systems. Agroforestry Systems 61 :281-295. Retrieved from https://doi.org/10.1007/978-94-017-2424-1_20

Nair, P.K.R., Kumar, B.M. \& Nair, V.D. (2009). Agroforestry as a strategy for carbon sequestration. J Plant Nutr Soil Sci., 172 :10-23. Retrieved from https://doi.org/10.1002/jpln.200800030

Njoukam, R. (1997). Effets de différents prétraitements sur la germination des semences de l'aiélé (Canarium schweinfurthii Engl.). Revue Sciences et Techniques, Série Agronomie et Zootechnie. 3 (4) : 67-81.

Njoukam, R. (1998). Germination des semences et croissance de l'aiélé (Canarium schweinfurthii Engl.) en plantation. In Kapseu, C. \& Kayem, J. (éds) : Actes du 2ème séminaire international sur la valorisation du safou et d'autres oléagineux non conventionnels, 3-5 décembre, Ngaoundéré, Cameroun. P: 185-192.

Njoukam, R. \& Peltier, R. (2002). L'aiélé (Canarium schweinfurthii Engl.) : Premier essai de plantation dans l'Ouest du Cameroun. Fruits., 57 (04) : 239-248. Retrieved from https://doi.org/10.1051/fruits:2002021

Njoukam, R., Temgoua, L. \& Peltier, R. (2008). Dans l'Ouest-Cameroun, les paysans ont préservé les arbres dans leurs champs, pendant que l'Etat laissait brûler ceux qu'il avait plantés dans ses réserves. International IUFRO Conference 
on Traditional Forest-related Knowledge and Sustainable Forest Management in Africa, Accra, Ghana, $\mathrm{p}$ :14-17. Retrieved from https://agritrop.cirad.fr/547325/1/document_547325.pdf

Plan Communal de Développement (PCD). (2013). Plan de la commune de Mbouda réalisé par l'Appui au Développement Intégral sur le financement du Programme National de Développement Participatif (PNDP), 316 p. Retrieved from https://tel.archives-ouvertes.fr/tel-02937356/

Saj, S., Jagoret, P. \& Todem Ngogue, H. (2013). Carbon storage and density dynamics of associated trees in three contrasting Theobroma cacao agroforests of Central Cameroon. Agroforestry Systems., 87: 1309-1320. Retrieved from https://doi.org/10.1007/s10457-013-9639-4

Saj, S., Durot, C., Mvondo-Sakouma, K., Tayo Gamo, K. \& Avana-Tientcheu, M.L. (2017). Contribution of companion trees to long-term tree conservation, carbon storage and agroforest sustainability: a functional analysis of the diversity in cacao plantations of Central Cameroon. International Journal of Agricultural Sustainability., 15: 282-302. Retrieved from https://doi.org/10.1080/14735903.2017.1311764

Schoeneberger, M.M. (2009). Agroforestry: working trees for sequestering carbon on agricultural lands. Agroforestry Systems., 75 : 27-37. Retrieved from https://doi.org/10.1007/s10457-008-9123-8

Tchatchouang, L.F.C, Djomo, C.C, Tajeukem, V.C, Djibrillia, P. \& Happi, Y.J. (2018). Diversity, structure and carbon stocks from three pools in the Kouogham sacred forest, hedgerows and Eucalyptus plantations in the Batoufam locality (West Cameroon). Applied Ecology and Environmental Sciences., 6(4) : 160-169. Retrieved from https://doi.org/10.12691/aees-6-4-7

Tchouamo, I.R., Tchoumboue., Simonet, M.A. \& Pinta, J.Y. (2000). La commercialisation des fruits de l'aiélé (Canarium schweinfurthii Engl) dans les hautes terres de l'Ouest du Cameroun. La Rivista Italiano Delle Sostance Grasse., 77(10) : 677-680. Retrieved from http://pascalfrancis.inist.fr $/ \mathrm{vibad} /$ index.php?action=getRecordDetail\&idt=869658

Temgoua, L.F., Dongmo, W., Nguimdo, V. \& Nguena, C. (2018). Diversité Ligneuse et Stock de Carbone des Systèmes Agroforestiers à base de Cacaoyers à l'Est Cameroun. Journal of Appied Biosciences., 122 : 12274-12286. Retrieved from https://doi.org/10.4314/jab.v122i1.7

Temgoua, L.F, Momo, S.M.C \& Boucheké, R.K. (2019). Diversité floristique des ligneux des systèmes Agroforestiers cacaoyers du Littoral Cameroun: cas de l'Arrondissement de Loum. European scientific Journal., 15(9) : 62-83. Retrieved from https://doi.org/10.19044/esj.2019.v15n9p62

Tsewoue, M.R. (2013). Contribution de Canarium schweinfurthii (Engl) (Burseraceae) aux services écosystémiques des agroforêts caféières du Département de Bamboutos (Ouest, Cameroun). Thèse master, Université de Dschang, p 96.

Tsewoue, M.R, Avana, T.M.L. \& Tchoundgjeu, Z. (2019). Etude ethnobotanique et contribution de Canarium schweinfurthii (Engl) (Burseraceae) aux services écosystémiques des agroforêts à base de caféiers dans le Département de Bamboutos (Ouest, Cameroun). Journal of Applied Biosciences., 135: 1380813820. Retrieved from https://doi.org/10.4314/jab.v135i1.7

Tsoumou, B., Lumandé, K., Kampé, J. \& Nzila, J. (2016). Estimation de la quantité de Carbone séquestré par la Forêt Modèle de Dimonika (Sud-ouest de la République du Congo). Revue Scientifique et Technique Forêt et 
Environnement du Bassin du Congo., $6: 39$ - 45. Retrieved from https://www.revue.riffeac.org/index.php?journal=RSTBC\&page=article\&o $\mathrm{p}=$ view \&path $\% 5 \mathrm{~B} \% 5 \mathrm{D}=74$

Vivien, J. \& Faure, J.J. (2012). Arbres des forêts denses d'Afrique centrale. Espèces du Cameroun. Paris, France, Agence de coopération culturelle et technique. P 954.

Zafack, L., Engwald, S., Sonke, B., Achoundong, G. \& Madong, B.A. (2002). The impact of land use conversion on plant biodiversity in the forest zone of Cameroon. Biodiversity Conserv., 2 : 2047-2061. Retrieved from https://doi.org/10.1023/A:1020861925294 